http://dx.doi.org/10.19183/how.24.1.310

\title{
Learners' Perceptions and Undergraduate Foreign Language Courses at a Colombian Public University
}

\author{
La percepción de los estudiantes sobre los cursos \\ de lenguas extranjeras a nivel de pregrado \\ en una universidad colombiana ${ }^{*}$
}

\author{
Ana Clara Sánchez Solarte \\ acsanchez@udenar.edu.co \\ Gabriel Vicente Obando Guerrero \\ gobando@udenar.edu.co \\ Diana Ibarra Santacruz \\ dianais@udenar.edu.co \\ Universidad de Nariño, Pasto, Colombia
}

This article reports the results of a study whose goal was to determine the views of undergraduate students regarding the English as a foreign language courses they must take as a requirement for graduation at a public university in Colombia. One hundred and thirty students from 10 undergraduate programs were surveyed and their responses were classified and analyzed. The findings indicate that learners are satisfied with the way foreign language courses are currently conducted. However, some aspects need further consideration and improvement. These suggestions are analyzed in this article.

Key words: Foreign language courses, foreign language methodology, post method era.

* $\quad$ Received: May 20, 2016. Accepted: November 9, 2016.

How to cite this article (APA 6th ed.):

Sánchez Solarte, A. C., Obando Guerrero, G. V., \& Ibarra Santacruz, D. (2017). Learners’ perceptions and undergraduate foreign language courses at a Colombian public university. HOW, 24(1), 63-82. http://dx.doi. org/10.19183/how.24.1.310.

This article is licensed under a Creative Commons Attribution-NonCommercial-NoDerivatives 4.0 International License. License Deed can be consulted at http://creativecommons.org/licenses/by-nc-nd/4.0/. 
Este artículo presenta los resultados de una investigación cuyo objetivo era determinar el grado de satisfacción que los estudiantes de pregrado en una universidad colombiana tienen con respecto a los cursos de inglés como lengua extranjera que deben tomar como requisito de grado. Se entrevistaron 130 estudiantes de 10 programas y sus respuestas fueron clasificadas y analizadas. Los resultados muestran que los estudiantes están satisfechos con los cursos de lengua extranjera. Sin embargo, hay una serie de aspectos que requieren mayor consideración y mejora. Esos aspectos se analizan en este artículo.

Palabras clave: cursos de lengua extranjera a nivel de pregrado, metodología de lenguas extranjeras, post-método.

\section{Introduction}

Historically, learning a foreign language and administering foreign language (L2) courses have been a constant need for academic, personal, and economic reasons (CelceMurcia, 2001). In Colombia, the Ministerio de Educación Nacional (MEN) issued Law 115 (1994), the Curricular Guidelines for English Teaching (1996), and the Basic Competence Standards for English (MEN, 2006), among others, establishing that foreign language instruction needs to be part of the educational experience of Colombian students at all levels. The relevance given to learning foreign languages as part of the foundation for an individual's professional life was further advanced by the government in 2004 with the National Plan of Bilingualism (MEN, 2004), a program and a policy that, as a 2015 report by the British Council suggests

was created mainly to improve the economic and human resources development by means of an increase of participation in global economy, which is mainly English-bound. The access to resources, business, education, and technology in English was seen as key for growth, while the resulting participation of Colombians in exchanges and multicultural agreements were identified as potential triggers for development. (p.13)

The need for another language seems clearly established, but informal comments made by undergraduate students hinted that they saw these L2 courses as an obstacle for graduation, lacking the importance other courses have.

This research emerged, then, to cope with the absence of information regarding the strengths and weaknesses of L2 courses; up to now, teachers and administrators did not have a solid idea of students' perceptions about these courses. The study provides a clearer understanding of the needs and expectations students currently have, so that a proposal and additional learning support (e.g., placement tests, materials) can be procured trying to match those needs and expectations with the university goals.

The excerpt was translated from Spanish. 


\section{Literature Review}

Before discussing how learners perceive foreign language courses, some key concepts related to L2 instruction are reviewed: foreign language instruction, post method, and L2 instruction at tertiary levels.

\section{A Brief Overview of Foreign Language Instruction}

The evolution of foreign language teaching (FLT) has been discussed by Richards and Rodgers (2001), Celce-Murcia (2001), and Richards (2008), among others. Celce-Murcia states that two main trends have prevailed in L2 instruction: teaching a language so that the apprentice can communicate with NSs (Native Speakers) of that language and function in that society, or, teaching a language in order to analyze its formal aspects (e.g., grammar and vocabulary), that is, learn about that L2. The different methods that emerged along history reflect the needs of learners at a given point in history. For instance, in the 16th century people learned a language to communicate with Europeans in their vernacular languages, while in the 19th century, learning a language was more a mental drill done to strengthen one's memory and enhance cognitive skills (Richards \& Rodgers, 1986, 2001, 2014). In 1929, the Coleman Report suggested that foreign language instruction for college students should be limited to teaching them to read academic texts in other languages. The second half of the 20th century was permeated by communicative language teaching (CLT) and interaction, authenticity, meaningful content, and learner needs. Content-based instruction, task-based language teaching, and cooperative-language learning feature these tenets. Teaching practices at institutions have been influenced by the different swings of the methodology pendulum, and in the latter part of the 20th century, L2 courses were focused on reading comprehension. However, it is important to remark that the Coleman Report is over 80 years old now and its suitability for our context needs to be evaluated.

After the predictable failure of the misconception that one single method is suitable for any teacher and learner, in any context, different authors suggested moving forward and exploring principles instead of simply adopting limiting procedures (Brown, 2002; Kumaravadivelu, 1994, 2003, 2006). As the 21 st century unfolds, teachers need to redefine their place in the teaching/learning process to enhance foreign language instruction.

\section{Defining Teaching in the 21st Century}

Teaching is a complex and multidimensional task and, as Brown (2007) suggests, it is both an art and a science. Hansen (as cited in Kumuravadivelu, 2003) differentiates the terms job, vocation, work, career, occupation, and profession to determine which one is more suitable to accommodate teaching. 
Kumaravadivelu (2003, p. 6) summarizes such categorization:

- a job is an activity that provides sustenance or survival comprising highly repetitive tasks not defined by those performing them.

- vocation goes beyond sustenance and survival; it guarantees personal autonomy and personal significance.

- work may ensure personal autonomy and can yield genuine personal meaning; unlike vocation, it need not imply being of service to others.

- a career describes a long-term involvement in a particular activity but it need not provide personal fulfillment, a sense of identity, or a public service.

- an occupation is an endeavor harbored within a society's economic, social, and political system, but may not entail a sense of calling in the same way vocations do.

- a profession broadens the idea of an occupation by emphasizing the expertise and the social contribution that persons in an occupation render to society.

Hansen (as cited in Kumuravadivelu, 2003) believes that vocation would best define what teachers do in their professional practice, but teachers' roles in the post method era are so varied that it might be accurate to say that teaching encompasses all these terms.

Brown (2002) advocates innovative roles for foreign language teachers and warns teachers against getting too comfortable:

There is far too much that we do not know collectively about this process, and there are far too many new research findings pouring in, to assume that a teacher can confidently assert that he or she knows everything that needs to be known about language and language learning. (p. 11)

Instead, he portrays teachers as agents that need to carry out a process of diagnosis, treatment, and assessment: In the first stage, teachers diagnose learners' needs, analyze the context where teaching takes place, and plan considering general pedagogical principles. Treatment refers to the application of that plan by means of suitable techniques that will enhance learning conditions. Finally, assessment deals with checking students' performance after the treatment. The information collected at this stage will allow teachers to introduce pedagogical changes that assist learners in attaining the initially set goals.

This framework might enhance the way foreign language courses are conducted at every level, and it fits in the post method pedagogy.

\section{The Post Method Pedagogy}

Given that Universidad de Nariño needs to prepare undergraduate students to face diverse tasks, some methodological principles need to be set. Teachers in charge of 
undergraduate foreign language courses need to plan, deliver, and assess lessons in a way that both communicative and academic goals are achieved. Kumaravadivelu (2006) suggests that L2 teachers situate themselves in the framework of the post method condition, which, the author explains, should lead us to challenge what we are doing in the classroom. The post method pedagogy can be "visualized as a three dimensional system consisting of three pedagogic parameters: particularity, practicality, and possibility" (Kumaravadivelu, 2006, p. 171).

These parameters are intertwined and affect each other: Particularity refers to teachers being aware of the fact that we are teaching a certain group of people, in a certain context, with specific goals, inside an institution with determined characteristics and affected by a sociocultural environment. This parameter gives importance to local knowledge and experience. Teachers need to be critical about many aspects: themselves, the concept of teaching, their practices and beliefs so they really understand what is and what is not feasible.

The second parameter, practicality, has to do with how we incorporate theory and practice to our teaching. Regarding this dichotomy, Kumaravadivelu (2006) explains that teachers are immersed in professional theories - those originated by experts — and in personal theories that come from the teacher's experience of bringing into practice professional theories. Teachers, according to this parameter, need to make extensive use of action research to build their own professional theories and sort out which ones are valuable for their classroom.

Finally, the parameter of possibility is based, as Kumaravadivelu (2006) states, on the ideas of Paulo Freire, who stated that pedagogy, power, and dominance are not separate entities, and that learners should challenge the secret agenda of education. This can be achieved by strengthening both students' and teachers' identity, by acknowledging the experiences that people bring into the classroom and by allowing those experiences to enrich and transform the teaching/learning process. English or any other language cannot be seen as an element dissociated from a sociopolitical context; furthermore, teachers need to be critical and make the best choices to maximize the likelihood of success in their classes under the given conditions.

\section{Learner-Centeredness}

Another piece of the methodology puzzle to consider when implementing changes in L2 instruction is the need to move towards learner-centeredness. Although this is not a new idea, classrooms in collectivistic cultures like the Colombian one seem to revolve around the teacher. With scarce time for instruction and the need to move towards communicative competence, teachers need to foster learner-centered classrooms where autonomy and responsibility are encouraged. Interestingly, teaching can be a learner-centered action. As Nunan (1999) affirms, the conception of language for communicative purposes redefined the role of teachers, and teaching might be characterized as the conscious act of providing people with enough opportunities to incorporate meaningful experiences in diverse settings 
Ana Clara Sánchez Solarte, Gabriel Vicente Obando Guerrero

and Diana Ibarra Santacruz

by motivating personal interests and through the exploration of different of sources, which eventually would benefit students.

\section{Experiences With Adult Learners}

Regarding L2 instruction at the tertiary level, numerous articles describe the issues found in these courses. Deckert (2004) discusses the cultural reasons why attempts to implement communicative language teaching often fail. Renaud, Tannenbaum, and Stantial (2007) analyze how to create student-centered lessons when dealing with large classes and limited resources. Locastro (2001) and Sarwar (2001) also address the challenges of working with large classes and the alternatives to overcome them. Similarly, $\operatorname{Ur}(1996,2012)$ and Brown $(1994,2007)$ analyze large classes with mixed ability levels. Others have focused on analyzing what needs to be changed in L2 instruction to make it more effective: Elyildirim and Ashton (2006) propose that L2 learning entails developing a certain understanding and appreciation towards the culture associated with the L2. Other scholars are concerned with implementing tasks with low L2 proficiency college students. Harshbarger (2007) explains from a theoretical perspective the elements to be included in L2 instruction, while Daley, Onwuegbuzie, and Bailey (1997) analyze the factors that predict the success of college students enrolled in L2 courses.

Literature focused on English for specific purposes (ESP) and English for academic purposes (EAP) is well-established and supported by methodology, technology, and psychology. Carter and Nunan (2001) include articles by Hamp-Lyons and Dudley Evans who discuss the approach used to teach an L2 to college students with specific needs, namely, ESP or EAP. Hamp-Lyons describes how research has advanced and describes how the areas of interest for EAP and ESP revolve around discourse analysis, verb analysis, and expressions. Along the same line, Geoghegan (as cited in Hamp-Lyons, 2001) reports a study at Cambridge University where the students' perspectives about L2 courses were different from those of teachers and administrators.

Colombian journals provide relevant local knowledge related to L2 instruction dealing with issues such as methodology, bilingualism, curricular innovation, design and application of materials, the use of technology, teaching practices, and assessment (Castellanos, 2009; Jaime Osorio \& Insuasty, 2015; Lastra, 2009; Rogers, 2008; Rojas Serrano, 2007; Sánchez Solarte \& Obando Guerrero, 2008).

Regarding college settings, a study done at Yuan Ze University in Taiwan (Yu-Ying, 2010) documents English-medium instruction in tertiary education. The paper reports the students' reactions to English as a medium of instruction (EMI) courses, the difficulties encountered in their EMI courses, and their English language learning needs observed during the research project. Researchers concluded that: 
1. Although students did not think they had a high level of comprehension of their EMI lectures, they displayed positive attitudes towards the courses, probably due to their professors' efforts to reduce anxiety levels.

2. The participants agreed that English instruction helped them improve their English language proficiency, especially in terms of listening.

3. EMI subject courses can be opportunities to improve the English language proficiency of undergraduate students.

4. If universities do not have sufficient resources, strategies worth considering include offering voluntary, non-credit-bearing language courses that students pay for, or allowing participation in EMI courses only to proficient English students.

This study provides some insights that could be translated to our context. For instance, it can be suggested that undergraduate programs include at least one course conducted in a foreign language in their curriculum.

Another study was conducted in China (Guo \& Li, 2004), an EFL context displaying problems and experiences that can be similar to ours. The need to interact with other countries led the Chinese government to start a process to increase the English proficiency of the population, especially in tertiary education. One step the Chinese Ministry of Education took in this direction was to revise the English teaching syllabus focused on text-based comprehension, and change it to one focused on listening and speaking. This change implied a shift towards learner-centered learning and towards considering aspects for creating a language course, including:

- Culture seen as an important aspect in the teaching-learning process.

- The importance of a close relation between students' objectives and the institution objectives.

- The English proficiency students have before starting the language course.

- The number of students per group.

- The creation of spaces where students can practice the language.

- The role of technology in learning.

- The commitment of the institution to provide the necessary tools and equipment for lessons to develop smoothly.

- The inclusion of autonomous learning and collaborative group learning in the teaching process. 
Ana Clara Sánchez Solarte, Gabriel Vicente Obando Guerrero

and Diana Ibarra Santacruz

\section{Method}

\section{Participants}

One hundred and thirty undergraduate students from civil engineering, psychology, biology, systems engineering, sociology, law, the BA program in teaching natural sciences, physics, zootechnics, and social sciences took part in the process. The sample was chosen by means of a random sampling by listings; thus choosing a significant number of participants with different academic backgrounds and experiences in L2 learning.

\section{Context}

This project was carried out with students enrolled in foreign language courses at Universidad de Nariño. Every student, regardless of his/her major, must take six hours of instruction every week for two semesters. Each class has around 25 students from different majors, and the goal is to develop a basic command of language skills (listening, speaking, reading, writing) and language components (vocabulary, grammar, pronunciation) to face communicative exchanges that match the government's demands, namely, a B2 level according to the Common European Framework of Reference (CEFR).

\section{Type of Research and Design}

Given that the goal of the study was to determine how satisfied undergraduate students at Universidad de Nariño were regarding English as a foreign language (EFL) courses, the model used was mixed. That is, quantitative and qualitative paradigms were used in order to increase the validity of the data collected and make sure that relevant information was not omitted. The design was transversal and descriptive. This combination allowed researchers to register, describe, and analyze the students' degree of satisfaction regarding their foreign language learning experience and use the information to enhance those courses.

\section{Instruments and Data Collection Procedures}

The instrument had 32 Likert-type questions related to satisfaction in six dimensions: the course, student performance, teacher-student interaction, assessment practices, facilities and resources, methodology; and one open-ended question aimed at collecting suggestions about the courses (see Appendix). The items were designed by three foreign language teachers and a psychologist, which ensures a valid measure of how satisfied learners are with L2 courses. The reliability level was high $(\alpha=0.92)$. The questions were written in Spanish in order to avoid ambiguity or misunderstandings. 


\section{Results}

Once the information provided by the learners was compiled, the data were run through a statistics analysis program, the SPSS 19, which allowed us to obtain descriptive information about the surveys. This information was compared with existing bibliography related to L2 teaching.

\section{Close-Ended Questions (Likert)}

The first step to conduct the analysis was to transform the answers into a continuous variable. The different answer options had a higher or lower value according to the degree of agreement regarding the 32 statements: 5 (totally agree), 4 (agree), 3 (neither agree, nor disagree), 2 (disagree), 1 (totally disagree). This led to establish a theoretical mean and cut-off points for the categories. This was the basis for re-coding the average of each participant's answers for a particular category in one of these satisfaction levels: (1) unsatisfied, (2) moderately satisfied, (3) very satisfied. The answers provided by the surveyed students show that there is an overall positive assessment in the way foreign language courses are currently administered and are summarized Figures 1 to 6.

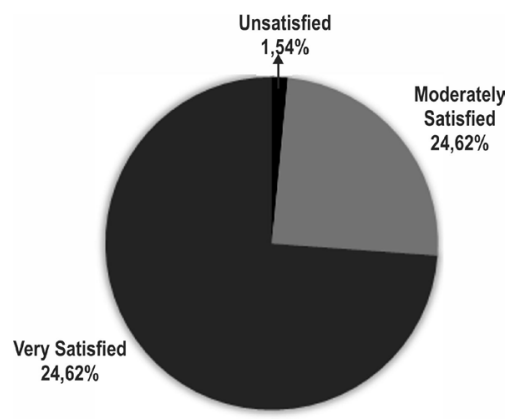

Figure 1. Satisfaction With the Implemented Methodology

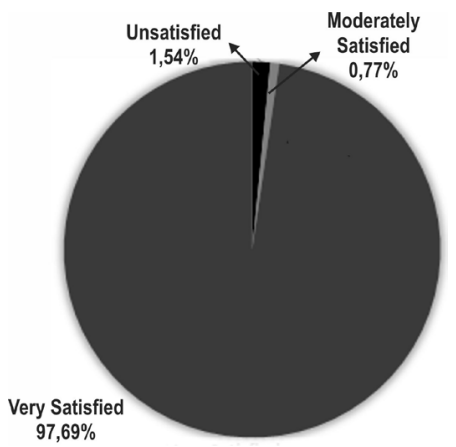

Figure 2. Satisfaction With the Teachers 
Ana Clara Sánchez Solarte, Gabriel Vicente Obando Guerrero and Diana Ibarra Santacruz

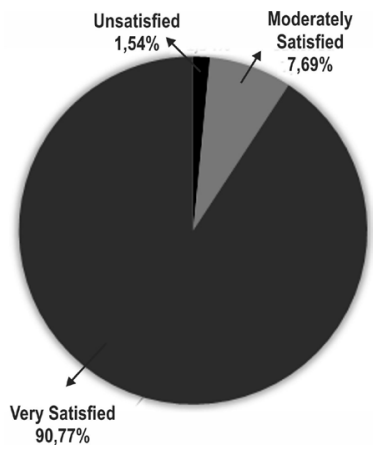

Figure 3. Satisfaction and Performance

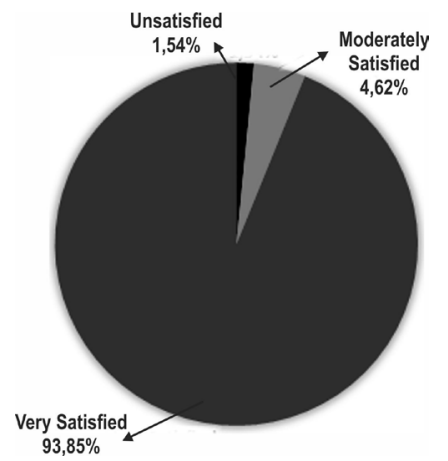

Figure 4. Satisfaction With Assessment Practices

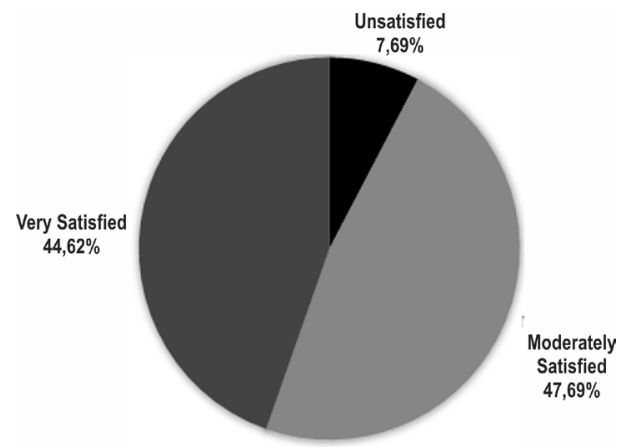

Figure 5. Satisfaction With Facilities and Resources 


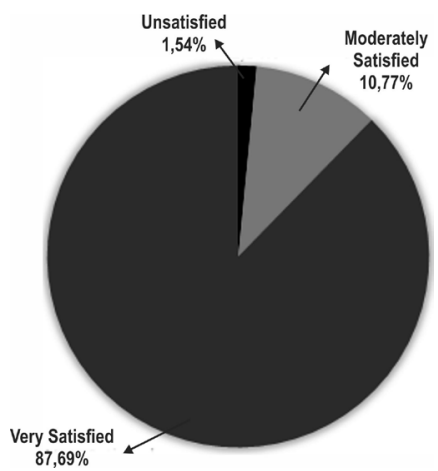

Figure 6. General Satisfaction - General Scale

The results drawn from the closed-ended questions indicate a sense of satisfaction with foreign language courses, especially with teachers' performance. The overall positive trend diminished when considering facilities and resources for teaching.

\section{Open-Ended Question}

The question was: Could you provide three suggestions to make foreign language courses more effective? The 258 suggestions obtained from the surveyed students were analyzed and grouped in the categories discussed next.

Assessment. A number of participants stated the need to receive training and exposure to standardized and placement/diagnostic tests given that, in academic settings, students take standardized tests to measure the proficiency of people whose native language is not English, or to help institutions determine whether test takers are eligible to enroll in Englishspeaking universities based on their language abilities. The fact that learners are aware of the importance of these tests is encouraging. The suggestions can be translated as exposing learners to classroom tasks that mirror standardized tests.

Administering placement tests was another suggestion. For Bailey (1998) placement tests attempt to define student's language skills considering the levels of the particular program learners are about to enter. First-semester students might take such a test in order to enroll directly in a more advanced course. This strategy may help the institution make a more sensible use of resources since the demand for elementary level courses may decrease.

Facilities. As Brown $(2004,2007)$ and Harmer (2007) suggest, classroom management and even the validity of assessment can be affected by the context where the teaching/ learning process takes place. In the survey, students call for a widespread use of information 
and communications technologies (ICTs) in L2 classes. They are digital natives born in an era where every aspect of life is permeated by technology, and language learning should not be the exception. Students request more hours in the language lab, and computers for language learning; they believe multimedia tools would help them improve pronunciation and listening. Considering these suggestions, school directors indicate five smart TVs, new computers, and four sound system units are now available.

Methodology. This category encompasses the perception and expectations students have about teachers and learning experiences. These expectations, as Brown (2007) suggests, depend on culture. In the context with which the study was done, students consider the teacher, not themselves, the center of the learning activity. Methodology was a sensitive area for participants as they made 83 suggestions connected to these issues.

Lesson planning. The students state that lessons should incorporate a wider variety of elements that stimulate listening and speaking, and which add dynamism to class interaction. Students are aware of the fact that there is planning behind the learning experiences they have, and skills are integrated and balanced in these course, but they said that, sometimes, lessons were too focused on grammar, vocabulary, or writing.

Teaching aids. A number of authors within the field of TESOL such as Ur (1996, 2012), Harmer (2007), Brown (2004, 2007), and Scrivener (2011) agree that materials are necessary for instruction since they bring variety to lessons, change the pace of the class, help students focus on a certain skill, and contribute to creating a more relaxed environment. Learners are aware of their importance and suggest the use of varied, updated, authentic, and interesting materials in the L2 class including Internet, movies, CDs, DVDs, audio and visual materials, readings, and anything that encourages learning and prevents monotony. It is worth mentioning that unlike other universities in Colombia, students at Universidad de Nariño do not pay for L2 courses. Thus, the funding for equipment and materials might be limited. However, teachers can use Facebook pages, blogs, or online courses to support learning. Blended learning is an option to bring Kumaravadivelu's post method into the L2 classroom maximizing learning opportunities, promoting learner autonomy, and integrating the skills by means of technology.

Lesson development. Divergent answers were gathered regarding the nature of L2 courses: Some participants want them to focus on productive skills, while others think that L2 courses must feature content related to their major, that is, ESP. In order to find a middle ground, the use of content-based instruction (CBI) might be a feasible option since it displays features that reconcile these two views: both teacher and students are held accountable for content, it encourages the use of relevant and appropriate authentic and modified texts and exams, and it offers a natural context for developing academic skills (note taking, paraphrasing, summarizing) that can extend to other courses; it uses vocabulary instruction and reading strategies to incorporate specific content, language emerges from 
content and social interaction, and content is learned and taught in L2 (Center for Advanced Research on Language Acquisition, 2014).

CBI can work with task-based language teaching (TBLT) principles. TBLT is closely connected to real-life needs and tasks, language learning is meaningful (i.e., class activities include taking mock exams, doing presentations about their programs, preparing an interview for a scholarship), interaction is promoted, students share responsibility of their work, tasks are motivating and challenging and involve communicative language use and metalinguistic reflection (Van den Branden, 2012).

Classroom management. Brophy (1983) defines it as a teacher's efforts to establish and maintain the classroom as a pleasant and positive environment for teaching and learning. Inside classroom management are discipline and attendance, two aspects discussed in the surveys. Students suggested that there should be negative consequences for those who miss class, are late, do not comply with classroom rules, or neglect homework. They even recommend having more homework, demanding students use only the L2 in class, and assigning challenging tasks from the very beginning.

Interaction and tasks. Students have diverging views concerning L2 use in the classroom. Some are adamant about conducting the class and interacting entirely in English, but others want teachers to translate everything they say into Spanish. Regarding tasks, learners want to do oral presentations and games in English, and even suggest having a coffee time to use the L2. These suggestions are motivating and challenging: As suggested earlier, teachers need to assume new roles, and be bold when it comes to innovating in the classroom.

Students' attitude. It is interesting to notice that while some programs at the University discourage their students from taking foreign language courses (e.g., Law School) the participants suggested adding more semesters in order to achieve communicative competence. This positive attitude towards learning a foreign language is reflected in their wanting to communicate in that L2 and interact with Native Speakers (NSs) of other languages. This contact would be beneficial for students and, since the institution has agreements with ICETEX and AIESEC, the goal of having learners interact with NSs of English, French, or Italian is realistic.

Schedules and time for the courses. Students propose flexible times for L2 courses and scheduling them during vacation time, so they can devote their time completely to learning a language. They also recommended avoiding 3-hour class sessions because this hinders learning instead of fostering it. Finally, some learners want demanding lessons, but others suggest reducing the number of hours so they have time for the tasks associated directly with their majors.

Other curricular aspects. Curriculum encompasses the whole educational experience and ranges from syllabus design, schedules, or the general content of lessons to the changes 
needed to support learning in a more effective way. Regarding course content, students had conflicting views: some state that in elementary and high school they should have acquired a basic knowledge of English, and foreign language courses should start at a more advanced level. For others, L2 courses should begin with basic topics since students who come from small towns in Nariño may not have studied foreign languages at all. The general perception was that there are dissimilar proficiency levels among the learners and they feel teachers should do something to try to overcome this lack of homogeneity (e.g., using diagnostic tests).

\section{Conclusions}

This study aimed at exploring students' perceptions regarding the L2 courses they took at Universidad de Nariño. The findings also offer teachers and administrators a template to follow when re-designing or adapting current teaching practices.

Quantitative data indicate that the category displaying the highest degree of satisfaction is that of teachers, followed by the categories of assessment, students' satisfaction with their own performance, and methodology. The category with the lowest degree of satisfaction was that of facilities and teaching resources. On the whole, the answers reflected a generalized sense of satisfaction with foreign language courses.

Some conclusions related to the learners' suggestions are the following:

The content of undergraduate L2 courses needs to feature a combination of functions and tasks. Additionally, activities highlighting genre-based teaching need to be made explicit in the course syllabus to reach a two-fold goal: developing language and specific content.

Students call for varied assessment tasks that integrate the skills and provide for preparation for standardized tests such as TOEFL. This means that learners are aware of the importance of taking internationally recognized tests and want to move towards this goal.

Administrators, teachers, and students need to agree on the organization, mechanisms, and expected results from undergraduate L2 classes, and fund these initiatives. Teachers can gain great understanding of learning processes and conditions through research, but resources are needed to support these initiatives.

Placement tests are needed to prevent teachers from working with mixed-ability-level students. In fact, a placement test created by the members of the Universidad de Nariño research group and the English teacher assistants was piloted in April, 2016. Subsequent washback and research will provide information about its suitability in addressing students' needs and might provide a background for introducing changes in syllabi, methodology, schedules, grouping, class size, and assessment. 
To conclude, even though mixed perceptions regarding learning a language exist, it is promising to discover that students want to learn to communicate in another language in order to achieve different objectives. The idea of taking L2 courses merely to be able to translate technical documents is being challenged.

Teachers need to innovate and provide learners with strategies related to autonomous learning, cooperative learning, and any interactive strategy linked to communicative principles, giving students the power to be agents of learning and teaching.

\section{References}

Bailey, K. M. (1998). Learning about language assessment: Dilemmas, decisions and directions. Pacific Grove, US: Heinle \& Heinle Publishers.

British Council. (May, 2015). El inglés en Colombia: estudio de politicas, percepciones y factores influyentes [English in Colombia: A study on policies, perceptions, and influential factors]. Retrieved from https://www.britishcouncil.co/sites/default/files/colombia_version_final_-_espanol.pdf.

Brophy, J. E. (1983). Research on the self-fulfilling prophecy and teacher expectations. Journal of Educational Psychology, 75(5), 631-661. https://doi.org/10.1037/0022-0663.75.5.631.

Brown, H. D. (1994). Teaching by principles: An interactive approach to language pedagogy (2nd ed.). White Plains, US: Prentice Hall Regents.

Brown, H. D. (2002). English language teaching in the "postmethod" era: Toward better diagnosis, treatment, and assessment. In J. C. Richards \& W. A. Renandya (Eds.), Methodology in language teaching: An anthology of current practice (pp. 9-18). Cambridge, UK: Cambridge University Press. https://doi.org/10.1017/CBO9780511667190.003.

Brown, H. D. (2004). Language assessment. Principles and classroom practices. White Plains, US: Pearson Education.

Brown, H. D. (2007). Teaching by principles: An interactive approach to language pedagogy (3rd ed.). White Plains, US: Prentice Hall Regents.

Carter, R., \& Nunan, D. (Eds.). (2001). The Cambridge guide to teaching English to speakers of other languages. Cambridge, UK: Cambridge University Press. https://doi.org/10.1017/ CBO9780511667206.

Castellanos, A. (2009). Fostering communication through blogs in an international, multi-grade context. HOW, 16(1), 151-166.

Celce-Murcia, M. (Ed.). (2001). Teaching English as a second or foreign language (3rd ed.). Boston, US: Heinle \& Heinle.

Center for Advanced Research on Language Acquisition. (2014). Characteristics of CBI. Retrieved from http://carla.umn.edu/cobaltt/modules/principles/characteristics.html.

Daley, C. E., Onwuegbuzie, A. J., \& Bailey, P. (1997). Predicting achievement in college level foreign language courses. Retrieved from ERIC database. (ED415273) 
Deckert, G. (2004). The communicative approach: Addressing frequent failure. English Teaching Forum, 42(1), 12-17.

Elyildirim, S., \& Ashton, S. (2006). Creating positive attitudes towards English as a foreign language. English Teaching Forum, 44(4), 2-21.

Guo, N., \& Li, D. (2004). An ongoing teaching experimental project of EFL in a Chinese tertiary education context. Paper presented at the AARE Annual Conference, Melbourne, Australia. Retrieved from http://www.aare.edu.au/data/publications/2004/nai04371.pdf.

Hamp-Lyons, L. (2001). English for academic purposes. In R. Carter \& D. Nunan (Eds.), The Cambridge guide to teaching English to speakers of other languages (pp. 126-130). Cambridge, UK: Cambridge University Press. https://doi.org/10.1017/CBO9780511667206.019.

Harmer, J. (2007). How to teach English. Harlow, UK: Pearson.

Harshbarger, B. (2007). Chaos, complexity and language learning. Language Research Bulletin, 22, 17-31.

Jaime Osorio, M. F., \& Insuasty, E. A. (2015). Analysis of the teaching practices at a Colombian foreign language institute and their effects on students' communicative competence. $\mathrm{HOW}$, 22(1), 45-64. https://doi.org/10.19183/how.22.1.133.

Kumaravadivelu, B. (1994). The postmethod condition: (E)merging strategies for second/foreign language teaching. TESOL Quarterly, 28(1), 27-48. https://doi.org/10.2307/3587197.

Kumaravadivelu, B. (2003). Beyond methods: Macrostrategies for language teaching. New Haven, US: Yale University Press.

Kumaravadivelu, B. (2006). Understanding language teaching: From method to postmethod. New York, US: Routledge.

Lastra, S. P. (2009). An understanding of the concept and conditions of bilingualism: A study in an EFL setting. HOW, 16(1), 167-187.

Locastro, V. (2001). Large classes and student learning. TESOL Quarterly, 35(3), 493-496. https:// doi.org/10.2307/3588032.

Ministerio de Educación Nacional, MEN. (1994). Ley general de educación [Colombian general law of education]. Bogotá, CO: Author.

Ministerio de Educación Nacional, MEN. (1996). Lineamientos curriculares idiomas extranjeros [Curricular guidelines for the teaching of foreign languages]. Bogotá, CO: Author.

Ministerio de Educación Nacional, MEN. (2004). Plan nacional de bilingüismo [National Bilingual Plan]. Bogotá, CO: Author.

Ministerio de Educación Nacional, MEN. (2006). Estándares básicos de competencias en lenguas extranjeras: inglés [Basic standards for foreign languages: English]. Bogotá, CO: Author.

Nunan, D. (1999). Second language teaching and learning. Boston, US: Heinle \& Heinle.

Renaud, S., Tannenbaum, E., \& Stantial, P. (2007). Student-centered teaching in large classes with limited resources. English Teaching Forum, 45(3), 12-17.

Richards, J. C. (2008). Growing up with TESOL. English Teaching Forum, 46(1), 2-11.

Richards, J. C., \& Rodgers, T. S. (1986). Approaches and methods in language teaching (1st ed.). Cambridge, UK: Cambridge University Press. 
Richards, J. C., \& Rodgers, T. S. (2001). Approaches and methods in language teaching. (2nd ed.). Cambridge, UK: Cambridge University Press. https://doi.org/10.1017/CBO9780511667305.

Richards, J. C., \& Rodgers, T. S. (2014). Approaches and methods in language teaching. (3rd ed.). Cambridge, UK: Cambridge University Press.

Rogers, A. (2008). Using technology to facilitate process writing and interaction among adult students. PROFILE Issues in Teachers' Professional Development, 9(1), 197-218.

Rojas Serrano, J. (2007). Technology applied to ELT: Reviewing practical uses to enhance English teaching programs. HOW, 14(1), 143-155.

Sánchez Solarte, A. C., \& Obando Guerrero, G. V. (2008). Is Colombia ready for "bilingualism"? PROFILE Issues in Teachers' Professional Development, 9(1), 181-195.

Sarwar, Z. (2001). Innovations in large classes in Pakistan. TESOL Quarterly, 35(3), 497-500. https://doi.org/10.2307/3588033.

Scrivener, J. (2011). Learning teaching: The essential guide to English language teaching. (2nd ed.). Oxford, UK: Macmillan.

Ur, P. (1996). A course in language teaching: Practice and theory (1st ed.). New York, US: Cambridge University Press.

Ur, P. (2012). A course in language teaching: Practice and theory (2nd ed.). New York, US: Cambridge University Press.

Van den Branden, K. (2012). Task-based language education. In A. Burns \& J. C. Richards (Eds.), The Cambridge guide to pedagogy and practice in second language teaching (pp. 132-139). Cambridge, UK: Cambridge University Press.

Yu-Ying, C. (2010). English-medium instruction for subject courses in tertiary education: Reactions from Taiwanese undergraduate students. Taiwan International ESP Journal, 2(1), 55-84.

\section{The Authors}

Ana Clara Sánchez Solarte holds an MA in TESOL/Linguistics from the University of Northern Iowa (USA). She is the director of the Lenguaje y Pedagogía research group. She is part of the Editorial Advisory Board for HOW Journal. Her interests include L2 methodology and assessment.

Gabriel Vicente Obando Guerrero is an associate professor at the Linguistics and Languages Department at Universidad de Nariño. He holds a Master's degree in TESOL/ Linguistics from the University of Northern Iowa (USA). He is a member of the research group Language and Pedagogy.

Diana Ibarra Santacruz holds a BA in English and French and an MA in English Linguistics from Radboud University (The Netherlands). She belongs to the Language and Pedagogy Research group at Universidad de Nariño. Her interests are second language acquisition, assessment, and methodology in language teaching. 


\section{Appendix: Survey for Students in Undergraduate Foreign Language Courses at a Colombian Public University ${ }^{2}$}

\section{Description:}

This survey was designed to gather information related to your experience as a student in the two levels of foreign language courses offered by the Department. This information will allow us to determine the degree of satisfaction regarding such courses.

The information collected will remain anonymous and will only be used for research purposes. Thanks for your cooperation.

I. Below you will find a series of statements related to different aspects of your experience as a student in the two levels of foreign language courses. Mark with an X the option you consider best describes the degree to which you agree or disagree with each of them.

\begin{tabular}{|c|c|c|c|c|c|c|}
\hline & Items & $\begin{array}{l}\text { Strongly } \\
\text { disagree }\end{array}$ & Disagree & $\begin{array}{l}\text { Neither } \\
\text { agree nor } \\
\text { disagree }\end{array}$ & Agree & $\begin{array}{l}\text { Strongly } \\
\text { agree }\end{array}$ \\
\hline 1 & Lessons start and finish on time. & & & & & \\
\hline 2 & $\begin{array}{l}\text { The contents presented at the } \\
\text { beginning of the course were } \\
\text { coherent with the ones you studied. }\end{array}$ & & & & & \\
\hline 3 & $\begin{array}{l}\text { The teacher conducts his/her } \\
\text { lessons using the target language. }\end{array}$ & & & & & \\
\hline 4 & $\begin{array}{l}\text { The teacher encourages students to } \\
\text { use the target language in class. }\end{array}$ & & & & & \\
\hline 5 & $\begin{array}{l}\text { The first and second level of the course } \\
\text { differ in terms of demands on student } \\
\text { performance (speaking and writing) }\end{array}$ & & & & & \\
\hline 6 & $\begin{array}{l}\text { My knowledge and performance in } \\
\text { the target language have improved } \\
\text { since I started the courses. }\end{array}$ & & & & & \\
\hline 7 & $\begin{array}{l}\text { I feel I am better able to understand } \\
\text { spoken language in the target } \\
\text { language thanks to what I have } \\
\text { learned in the courses. }\end{array}$ & & & & & \\
\hline
\end{tabular}

The original survey was applied in Spanish but has been translated for publication purposes. 

at a Colombian Public University

\begin{tabular}{|c|c|c|c|c|c|c|}
\hline & Items & $\begin{array}{l}\text { Strongly } \\
\text { disagree }\end{array}$ & Disagree & $\begin{array}{l}\text { Neither } \\
\text { agree nor } \\
\text { disagree }\end{array}$ & Agree & $\begin{array}{l}\text { Strongly } \\
\text { agree }\end{array}$ \\
\hline 8 & $\begin{array}{l}\text { I feel I am better able to } \\
\text { understand written texts in the } \\
\text { target language thanks to what I } \\
\text { have learned in the courses. }\end{array}$ & & & & & \\
\hline 9 & $\begin{array}{l}\text { I got the materials necessary to support } \\
\text { the learning process promptly. }\end{array}$ & & & & & \\
\hline 10 & $\begin{array}{l}\text { I promptly do the homework } \\
\text { assigned as part of the course. }\end{array}$ & & & & & \\
\hline 11 & $\begin{array}{l}\text { The language used by the teacher } \\
\text { when interacting inside the classroom } \\
\text { is appropriate and polite. }\end{array}$ & & & & & \\
\hline 12 & $\begin{array}{l}\text { The language used by the teacher } \\
\text { when interacting outside the } \\
\text { classroom is appropriate and polite. }\end{array}$ & & & & & \\
\hline 13 & $\begin{array}{l}\text { The teacher answers questions } \\
\text { related to the lesson. }\end{array}$ & & & & & \\
\hline 14 & $\begin{array}{l}\text { The evaluation criteria are promptly } \\
\text { presented by the teacher. }\end{array}$ & & & & & \\
\hline 15 & $\begin{array}{l}\text { The rules of the course are promptly } \\
\text { presented by the teacher. }\end{array}$ & & & & & \\
\hline 16 & $\begin{array}{l}\text { Assessment tasks are evenly } \\
\text { distributed throughout the semester. }\end{array}$ & & & & & \\
\hline 17 & $\begin{array}{l}\text { Assessment tasks are coherent with } \\
\text { the course objectives, contents and } \\
\text { the activities carried out in class. }\end{array}$ & & & & & \\
\hline 18 & $\begin{array}{l}\text { Assessment tasks demonstrate your } \\
\text { real performance as a student. }\end{array}$ & & & & & \\
\hline 19 & $\begin{array}{l}\text { Assessment tasks yield a final grade } \\
\text { that reflects the processes that } \\
\text { took place during the course. }\end{array}$ & & & & & \\
\hline 20 & Grades are turned in promptly. & & & & & \\
\hline 21 & $\begin{array}{l}\text { Assessment tasks are displayed } \\
\text { in the syllabus presented at the } \\
\text { beginning of the course }\end{array}$ & & & & & \\
\hline
\end{tabular}




\begin{tabular}{|c|c|c|c|c|c|c|}
\hline & Items & $\begin{array}{l}\text { Strongly } \\
\text { disagree }\end{array}$ & Disagree & $\begin{array}{l}\text { Neither } \\
\text { agree nor } \\
\text { disagree }\end{array}$ & Agree & $\begin{array}{l}\text { Strongly } \\
\text { agree }\end{array}$ \\
\hline 22 & $\begin{array}{l}\text { Assessment tasks cover the four } \\
\text { skills in a balanced fashion. }\end{array}$ & & & & & \\
\hline 23 & $\begin{array}{l}\text { Classrooms are appropriate for } \\
\text { teaching a foreign language. }\end{array}$ & & & & & \\
\hline 24 & $\begin{array}{l}\text { Teachers use a variety of teaching } \\
\text { strategies other than the textbook. }\end{array}$ & & & & & \\
\hline 25 & $\begin{array}{l}\text { Teachers make appropriate use of } \\
\text { audio-visuals during the course. }\end{array}$ & & & & & \\
\hline 26 & $\begin{array}{l}\text { Lessons include appropriate use of } \\
\text { technology (Internet, blogs, etc.). }\end{array}$ & & & & & \\
\hline 27 & $\begin{array}{l}\text { Teaching strategies focus on } \\
\text { developing communicative skills. }\end{array}$ & & & & & \\
\hline 28 & $\begin{array}{l}\text { Teaching strategies focus on } \\
\text { developing grammatical knowledge. }\end{array}$ & & & & & \\
\hline 29 & $\begin{array}{l}\text { Translation is a recurrent teaching } \\
\text { strategy in the course. }\end{array}$ & & & & & \\
\hline 30 & $\begin{array}{l}\text { Developing listening and speaking skills } \\
\text { has an important place in the course. }\end{array}$ & & & & & \\
\hline 31 & $\begin{array}{l}\text { Developing reading and writing skills } \\
\text { has an important place in the course. }\end{array}$ & & & & & \\
\hline 32 & $\begin{array}{l}\text { Course contents are supported by } \\
\text { the use of additional materials }\end{array}$ & & & & & \\
\hline
\end{tabular}

II. If any, could you make three suggestions for foreign language courses to be more effective? 